\title{
Capital Structure and Bank Performance: Empirical Evidence from Bangladesh
}

\author{
Md. Ibrahim Molla \\ Assistant Professor \\ Department of Finance and Banking, University of Barishal \\ Barishal-8200, Bangladesh \\ E-mail: mmibrahimfnb@gmail.com
}

Received: May 11, 2020 Accepted: June 11, $2020 \quad$ Published: June 11, 2020

doi:10.5296/ajfa.v12i1.17014 URL: https://doi.org/10.5296/ajfa.v12i1.17014

\begin{abstract}
The paper empirically investigates the relationship between capital structure and the performance of listed banks in Bangladesh using panel data over the period of five years from 2014-2018. To estimate the association between leverage level and bank performance the Panel Corrected Standard Error (PCSE) model is used in this study and the findings indicate that long term debt has a positive influence on the performance of banks which is measured in terms of ROA and ROE. This implies that long term debts are associated with the higher performance of banks listed in Bangladesh. The regression results also reveal that the capital structure component of total debt has no statistically significant impact on ROA, ROE and EPS but it has a significant positive impact on the performance of banks measured by price earning ratio. Furthermore, this analysis finds no relationship of long term debt and total debt with the EPS. These findings lead to conclude that capital structure has a weak to no influence on the performance of listed banks in Bangladesh. This paper is the first research attempt that investigates the impact of capital structure on the performance of all banks listed on the Dhaka Stock Exchange in Bangladesh.
\end{abstract}

Keywords: Capital structure, Leverage, PCSE, Banks, Bangladesh.

JEL Classification: $G$ 21, G 32 


\section{Introduction}

One of the main goals of a financial manager is to maximize the market value of the firm. The market value of the firm can be maximized by sound financing decisions where the financial manager uses the combination of debt and equity. A proper mixture of debt and equity would minimize the cost of capital and maximize the firm performance which in turn enhances the market value of the firm. The ratio of debt and equity and its relationship with firm performance has been the subject of a long line of investigation. This debate first started after the introduction of capital structure irrelevance theory propounded by Modigliani and Miller (1958), in which they claim that capital structure has no effect on the market value of the firm in an efficient market condition. MM negates the presence of optimal capital structure as the firm's market value is independent of its financing choices and concludes firms financing choices does not influence the performance of the firm. Opposing the MM structure, Kraus and Litzenberger (1973) propose that if the net tax benefits of debt financing equilibriums leverage related costs while keeping the company's assets and investment decisions constant, then the optimal capital structure can be found. He also believes a positive association between firms' leverage ratios and their performance which is later confirmed by (Chakraborty, 2010). Although several theories have been propounded to explain the capital structure of companies, and many of them suggest that the firm should optimize its capital structure but there is no consensus on how to achieve an optimal debt to equity ratio. For example, based on the perception that managers would not generally act to the greatest advantage of the investors, Jensen and Meckling (1976) concludes that an optimal capital structure is one that reduces the agency costs and by reducing the agency cost relating to managers and shareholders, debt can positively affect the firm's worth. Whereas, Myers and Majluf (1984) claim a negative relationship between capital structure and firm performance since more profitable firms opt to utilize internal financing over debt. The impact of corporation's capital structure on its financial achievement is still debated because some studies report positive relationship, for instance, Ghosh and Jain (2000); Hadlock and James (2002) while others document a negative association of debt with financial performance such as (Fama and French, 1998; Simerly and $\mathrm{Li}, 2000)$. The conflicting findings in the influence of debt ratio on firm's profitability motivate the researcher to carry out the study about the link between capital structure and firm's financial achievement focusing on the banks operating in Bangladesh. The commercial banks listed in the Dhaka Stock Exchange (DSE) have been chosen as a sample in this study for the following reasons. First, the financial market of Bangladesh is predominantly based on banks. The capital market of Bangladesh is undeveloped and less efficient so the economy remains reliant on bank financing to finance the large infrastructural development projects. The nature of large volatility with recurrent periods of boom and bust of stock markets in Bangladesh leads banks to play dominant roles in providing credit to non financial sectors, facilitating the central bank in executing the monetary policy, and in providing stability to the economy as a whole. So for the stability of the economy and accelerating the economic growth rate, the survivals of the banks are indispensable. The survival depends on the bank's performance and the performance of banks may be affected by the proper mixture of debt and equity as the inaccurate mixture of debt and equity can badly affect the performance and the value of the banks. The second reason for selecting the banking industry lies in the fact that the intense regulations, complex nature, 
and level of risk differentiate the capital structure of financial institutions such as banks from that of non-financial firms. Thirdly, as per the corporate governance guidelines of the Bangladesh Securities and Exchange Commission (BSEC), the separation of ownership and control of management is essential for the firms. This separation of ownership and control may result in mangers to accomplish their personal gains at the cost of the shareholders' interest or otherwise failing to maximize firm value. The choice of the capital structure may be one of the instruments that can help to reduce the agency cost of equity and increases firm value by constraining or encouraging managers to act more in favor of the shareholders.

The objective of this article is to examine the influence of capital structure on the performance of banks listed in the Dhaka Stock Exchange (DSE) over a period of five years from 2014 to 2018. The variables are selected based on the financial theories, previous empirical studies and the availability of data, including long-term debts on assets (LTD), total debts on assets (TD), growth opportunity of the banks, firm size, economic growth rate, and inflation as independent variables, while return on assets (ROA), return on equity (ROE), earnings per share (EPS) and price-earnings $(\mathrm{P} / \mathrm{E})$ ratio have been chosen as performance indicators. This study uses both the accounting and market-based measurements of firm performance. Accounting based measurements focus on the past financial performance of the firms, while market-based performance measurement focuses on the market expectation about the future growth of the firms (Demsetz and Villalonga, 2001).

This work is expected to make a number of contributions to the existing literature. First, it adds to the scarce empirical evidence on the topic of capital structure in Bangladesh's perspective. The majority of the prior studies on the effect of capital structure have been conducted in the context of developed economies and markets; there still exists a dearth of researches on this issue in the context of an emerging market like Bangladesh. A limited amount of study relating to this issue has been carried out using the data of Bangladeshi firms and in most cases; the researchers used the data of non-financial companies. A very few existing studies has been used the data of banks listed in the Dhaka Stock Exchange (DSE). Thus, the author considers it appropriate to examine how the capital structure of banks affects their performance. This is the first study where all banks listed in DSE are considered in the sample to investigate the effect of capital structure on the performance of banks, therefore expected to provide an overall scenario of the listed banking industry. Second, this analysis makes use of panel data methodology, which is more powerful in controlling for unobservable heterogeneity, a factor that is overlooked by the majority of prior studies. Finally, the use of the setting of the banking industry of a developing country like Bangladesh will facilitate the comparison with the context of other emerging economies.

The remainder of the paper is structured as follows. Section 2 discusses some empirical evidence regarding capital structure related literature and develops the various hypotheses for testing. Data, research methodology and econometric model are presented in section 3. Section 4 provides empirical results. Finally, section 5 will indicate the conclusions that can be derived from the empirical findings. 


\section{Literature Review}

Capital structure is considered as one of the powerful tools that could influence the firm's performance. But there involves the risk of bankruptcy to use the excess amount of debt in the firm's capital structure. If the bankruptcy cost exceeds the benefits of using debt in the form of tax deduction then firms may experience a lower amount of return. Recognizing the importance of capital structure, numerous studies concentrated on the impact of capital structure choices on firm's profitability as a measure of financial performance. Most of the empirical shreds of evidence suggest more or less influence on the firm's performance. However, the sign of the relationship is still inconclusive. Getahun (2016), using panel data of nine Ethiopian insurance companies over the period of 10 years, claims that the leverage has a negative impact on the performance which is measured by ROA. Similar results are reported by Ebaid (2009) who measures leverage in terms of STD and TD for the non-financial Egyptian listed companies for the period of 19997-2005, Rouf (2015) for the 106 manufacturing companies listed in Dhaka Stock Exchange (DSE) from 2008 to 2011, Nenu et al. (2018) for Romanian companies listed on the Bucharest Stock Exchange, Das and Swain (2018) for the manufacturing companies in India, Zeitun and Tian (2007) for the Jordanian companies during 1989-2003. Mursalim et al. (2017) investigated the leverage behavior of 94 Indonesian firms, 153 Malaysian firms, and 74 Thailand firms for the period of 2008-2012 and their result reflects the capital structure of firms is negatively related to the sampled firm performance measured by Economic Value Added (EVA), this finding is consistent with Nakhaei and Jafari (2015) for the companies listed on TSE. Similarly, Manawaduge et al. (2011) employ three leverage indicators such as total debt to total asset, total debt to equity ratio and short term total debt to total asset ratios to detect the impact of capital structure on the Srilankan's firm performance represented by ROA and Tobin's Q. Utilizing panel data fixed estimation regression model authors observe a negative association between these variables. In another study, Mwangi et al. (2014) apply Feasible Generalised Least Square (FGLS) regression to analyze the data of Nairobian non-financial firms and document a significant negative effect of financial leverage on ROA and ROE which is also affirmed by Siddik et al. (2017) by using panel data of 22 Bangladeshi banks for the period of 2005-2014.

Cole et al. (2015) use Long-Term liabilities to total assets ratio to detect the impact of debt on the performance of 30 U.S. firms in the Industrial, Healthcare, and Energy Sectors over 10 years of 2004 to 2013. Utilizing regression analysis the authors conclude that capital structure has a negative impact on return on assets and operating return in all three sectors whereas, the relationship between the capital structure and profit margin is not the same for all the sectors used in their study. They also claim no relationship between capital structures and stock prices in all three sectors. Recently, the paper of Khodavandloo et al. (2017) focuses on the trading and services sector of the Bursa Malaysia points out a strong negative impact of capital structure on firms' performance. Their study also reveals that the degree of association is stronger during the global financial crisis began in 2007 and ended in 2009 than pre and postfinancial crisis.

In contrast with the above findings, some empirical findings demonstrate the positive association between capital structure and firm performance. Musah and Gakpetor (2017) 
examine the relationship between capital structure and the profitability of NBFIs in Ghana taking a sample of 42 non-bank financial institutions over a period of 7 years from 2008-2014. Their results conclude that debt ratio which is a proxy of capital structure (DR) is positively associated with ROA of NBFIs in Ghana, which is partly relevant to the study of Saputra et al. (2015) who focus on the effect of capital structure on firm performance of the financial sector in the Indonesia Stock Exchange from 2009 to 2013 and using panel data analysis they come up with the findings that capital structure has a positive effect on banking and insurance sectors. Likewise, Goyal (2013) attempts to find the impact of capital structure on profitability of public sector banks in India listed on the national stock exchange from 2008 to 2012. Utilizing Regression Analysis he confirms a positive effect of short term debt on public sector bank's profitability as measured by ROE, ROA, which is related with the findings of Amin and Jamil (2015), Aramvalarthan et al. (2018). A part of such results is in line with Abor (2005) who reveals that short term debt to total assets and total debt to total assets have a positive impact on ROE for the firms of Ghana Stock Exchange. The author also claims a negative association between long term debt to total assets and ROE. However, the impact of capital structure components on each profitable measurement is not often identical. Mehar (2018) reports that long term debt ratio is negatively related to ROA and EPS, while short term and total debt ratios have a positive link with ROA and EPS by investigating 25 public and private banks listed on Pakistan Stock Exchange for the period of five years from 2011 to 2017 which is partly consistent with the findings of Vuong et al. (2017) who examine the effect of capital structure on the financial performance of the UK firms by using data of 739 very large and large companies listed on London Stock Exchange over the period of 10 years and their results depict long term liabilities has a negative relation with the firms financial performance measured by ROA and ROE but both short and long term liabilities affect Tobins' Q positively. Their study also reveals leverage has no impact on EPS. These results are opposing to Githire and Muturi (2015) who report equity and long term debt have a positive effect on financial performance, while short term debt has a negative effect on the financial performance of Nairobi firms by utilizing multiple regression analysis on the data of the firms listed on the Nairobi Securities Exchange from the year 2008-2013. The paper of Salim and Yadav (2012) focuses on the sample of 237 Malaysian listed companies on the Bursa Malaysia Stock exchange during 19952011 reports that short term debt (STD), long term debt (LTD), total debt (TD) have a negative influence on the accounting-based measurement such as return on asset (ROA), return on Equity( ROE) and earning per share (EPS) whereas short term debt (STD) and long term debt (LTD) have a positive effect on the market based-measurement such as Tobin's Q. Likewise, a positive association has been re-counted between the growth and performance of all sectors. Regarding the effect of the financial crisis, Olaniyi et al. (2015) reveal the debt-equity ratio has a negative relation with $\mathrm{ROE}$ before and after the global crisis but positive relation has been found with ROA in the post-crisis period. However, other variables that have been employed in this study have been found an insignificant relation with ROA. In addition to this, Al-Taani (2013) come up with the conclusion that capital structure is not a major determinant of firm performance by testing the relationship between capital structure and performance of 45 manufacturing companies listed on the Amman Stock Exchange over a period of five (5) years from 2005-2009. 
To sum up, it is clear from the above published empirical evidence that the effect of capital structure on firm's performance is inconclusive. The ambiguous results can be explained in a number of ways. First, the studies are conducted in different countries and different time periods are used in the studies by the researchers. The second reason may be due to the different analytical models are employed by the various researchers. Thirdly, the corporate internal policies regarding the financing and legal system of the countries differentiate the capital structure of firms in different countries. In addition to this, there may be some unobserved factors that can influence the firm's performance.

The previous empirical findings regarding the influence of leverage on firms financial performance is not beyond questionable. Thus it creates an avenue for the academicians, researchers, and regulators to analyze the impact of capital structure on the performance of banks operating in Bangladesh. Moreover, there are a few studies analyzing the impact of capital structure on the financial performance of all banks listed on the Dhaka Stock Exchange. An effort has been made by Siddik et al. (2017) to examine the impact of capital structure on the performance of banks in Bangladesh but their sample size was not large to go for a comprehensive analysis. Therefore, an endeavor has been taken to fill the void of the literature with a systematic analysis using the data of all the banks listed in DSE and this analysis expects to provide the comprehensive scenario of capital structure practices by the banks operating in Bangladesh.

\section{Methodology}

\subsection{Data}

To examine the impact of capital structure on the financial performance of banks listed in Dhaka Stock Exchange Ltd., this study uses 5-year period data from 2014 to 2018 whereby the firm-level data are sourced from the audited financial statements of the companies and the macroeconomic variables data are from the World Bank database. There are 30 banks listed on Dhaka Stock Exchange Ltd. as of 30 June 2019. The study uses balanced panel in this analysis.

\subsection{Measurement of the variables}

\subsubsection{Dependent variables}

The dependent variables of this study are the financial performance of banks. Both the accounting and market based performance measurements have been employed in this study to explore whether the independent variables explained the performance measures (accounting and market) at the same level or not. Accounting based performance measurements reflect the banks past performance and market based performance measurements indicate the expectations of the investor's future earnings of the banks. To measure the financial performance of bank four proxy variables have been employed in this study as a dependent variable such as Return on Assets (ROA), Return on Equity (ROE), Earning per Share (EPS) and Price Earnings (P/E) ratio. ROA, ROE and EPS are accounting-based measurements calculated from firms' financial statements, while $\mathrm{P} / \mathrm{E}$ ratio is used to measure the market performance of the banks. ROA and ROE have been used by different empirical studies as a measure of financial performance (such as Amin and Jamil, 2015; Akintoye, 2008; Salim and Yadav, 2012; Akintoye, 2008, Vuong et 
al., 2017), EPS by (Salim and Yadav, 2012; Mehar, 2018; Vuong et al., 2017) and P/E ratio has been used by Zeitun and Tian (2007). Their measurements are shown in Table-1.

Table 1. Name and definition of dependent variables

\begin{tabular}{|l|l|l|l|}
\hline $\begin{array}{l}\text { Sl. } \\
\text { No. }\end{array}$ & $\begin{array}{l}\text { Name of the } \\
\text { variables }\end{array}$ & $\begin{array}{l}\text { Variables } \\
\text { indicator }\end{array}$ & Measurement (Proxy) \\
\hline 1 & Return on Assets & ROA & Net Income (Before tax) /Total Asset \\
\hline 2 & Return on Equity & ROE & Net Income (Before tax) /Total Equity \\
\hline 3 & Earning per Share & EPS & Net Income / No. of Shares Outstanding \\
\hline 4 & Price-Earnings Ratio & P/E Ratio & Market price per share / Earning per share \\
\hline
\end{tabular}

\subsubsection{Independent Variables}

This study uses six independent variables comprising of four firm-specific factors such as long term debt ratio, total debt ratio, firm size, growth opportunities and two macroeconomic variables namely economic growth rate and inflation. Firm-specific factors such as firm size, growth opportunities and macroeconomic variables are used as controlled variables in this paper as it is expected that they may have an influence on the performance of banks. The size of a bank determines the level of economies of scale enjoyed by a bank. The bank size may influence its profitability as large banks have a greater capacity for dealing with adverse market fluctuations than the smaller ones (Ramaswamy, 2001; Frank and Goyal, 2003). Thus this study controls the variances in the firm's operating environment by introducing the size variable in the model. It is expected that highly growing banks have a chance to contribute positively to the performance ratio, as highly growing banks can generate higher profit from the investment. Economic growth rate and inflation rate have been employed in this research to measure the effect of the macroeconomic environment on the performance of the banks operating in Bangladesh. In the boom period, people will have idle money and they will purchase various products and savings schemes offered by the banks as well as the firms will undertake large profitable projects and vice-versa. This study uses log of GDP to measure the economic growth rate and it is expected that there is a positive association between the economic growth rate and bank's performance. On the other hand, during the inflationary period, the deposit holders will withdraw their money from the banks to meet up their daily expenses and when the inflation rises the people will have a fewer amount of savings. Moreover, banks have to offer highinterest rate on the deposits to collect money from the market and they will charge a higher interest rate on their credit. The cost of capital is higher during the inflationary period; as a result, the demand for the loan will be lower. By considering the above-mentioned consequences inflation rate has been applied in this research to see the impact on the performance ratios of banks. The number of independent variables and their measurements are summarized in the following table. 
Table 2. Name of independent variables and their definition

\begin{tabular}{|l|l|l|l|}
\hline $\begin{array}{l}\text { Sl. } \\
\text { No. }\end{array}$ & Name of the variables & $\begin{array}{l}\text { Variables } \\
\text { indicator }\end{array}$ & Measurement (Proxy) \\
\hline 1 & Long-term debt to total asset & LTD & Total long term debt / Total Assets \\
\hline 2 & Total debt to total asset & TD & Total debt / Total Assets \\
\hline 3 & Growth opportunity & GR & $\begin{array}{l}\text { (Assets of year } \text { - Assets of year } \text { ) / } \\
\text { Assets of year } 0\end{array}$ \\
\hline 4 & Firm's size & SIZE & Natural logarithm of total assets \\
\hline 5 & Economic growth rate & EGR & Natural logarithm of GDP \\
\hline 6 & Inflation rate & INF & The annual inflation rate \\
\hline
\end{tabular}

\subsection{Model Specification}

On the basis of the variables as mentioned earlier, we have designed the following multiple regression models to test the relationship between the firm's capital structure and its financial performance.

$$
\begin{aligned}
& R O A_{i t}=\alpha_{0}+\beta_{1} L T D_{i t}+\beta_{2} T D_{i t}+\beta_{3} S Z_{i t}+\beta_{4} G R_{i t}+\beta_{5} E G R_{i t}+\beta_{6} I N F_{i t}+\varepsilon_{i t} \\
& R O E_{i t}=\alpha_{0}+\beta_{1} L T D_{i t}+\beta_{2} T D_{i t}+\beta_{3} S Z_{i t}+\beta_{4} G R_{i t}+\beta_{5} E G R_{i t}+\beta_{6} I N F_{i t}+\varepsilon_{i t} \\
& E P S_{i t}=\alpha_{0}+\beta_{1} L T D_{i t}+\beta_{2} T D_{i t}+\beta_{3} S Z_{i t}+\beta_{4} G R_{i t}+\beta_{5} E G R_{i t}+\beta_{6} I N F_{i t}+\varepsilon_{i t} \\
& P / E \text { Ratio }_{i t}=\alpha_{0}+\beta_{1} L T D_{i t}+\beta_{2} T D_{i t}+\beta_{3} S Z_{i t}+\beta_{4} G R_{i t}+\beta_{5} E G R_{i t}+\beta_{6} I N F_{i t}+\varepsilon_{i t}
\end{aligned}
$$

Where, $\alpha_{0}$ represents constant. $\beta_{1}$ and $\beta_{2}$ indicate the regression coefficient for the leverage variables, namely LTD and TD respectively; $\beta_{3}$ and $\beta_{4}$ represent the regression coefficient for the firm-specific variables, namely SZ and GR respectively and $\beta_{5}$ and $\beta_{6}$ represent the regression coefficient for the macro-variables, namely EGR and INF respectively. $\varepsilon$ represents the error term, i refers to the individual banks and $t$ refers to the time period.

In this research endeavor, the panel data approach has been employed to determine the effect of capital structure on the bank's financial performance. Various tests were carried out to check if the panel data fulfilled the cardinal requirements of classical linear regression analysis include unit root test, multicollinearity test, heteroscedasticity test and autocorrelation test. These tests suggest heteroscedasticity and autocorrelation are present in the data. To overcome these problems, Prais-Winsten Panels Corrected Standard Error (PCSE) estimate has been applied in this study to investigate the association of capital structure and bank performance as it automatically corrects the problems of first-order autocorrelation and heteroscedasticity and offers the best estimates for the variables. PCSE has become the popular methods and widely used by the researchers as it preserves the weighting of observations for autocorrelation, but uses a sandwich estimator to incorporate cross-sectional dependence when calculating standard errors. Feasible Generalized Least Squares (FGLS) is an alternative method to PCSE that can solve the above mentioned problems but it is not the best choice in this case since the present study has a "large $\mathrm{N}$ and small T" panel dataset. 


\section{Empirical Findings}

\subsection{Descriptive Statistics}

This analysis examined the effect of capital structure on the financial performance of banking companies using a balanced panel of 30 banks over the period of five years from 2014-2018. Table 3 depicts the summary of descriptive statistics of the capital structure and Banks financial performance measures along with the control variables.

Table 3. Descriptive statistics

\begin{tabular}{lrrrrr}
\hline Variable & Obs. & Mean & Std. Dev. & Min & Max \\
\hline ROA & 150 & .841 & .783 & -4.25 & 2.36 \\
ROE & 150 & 11.046 & 5.037 & -4.44 & 22.16 \\
EPS & 150 & 2.733 & 2.516 & -4.56 & 21 \\
PE Ratio & 150 & 15.63 & 60.649 & -20.73 & 566.02 \\
TD & 150 & 8.268 & 32.035 & .091 & 290.005 \\
LTD & 150 & 3.244 & 15.199 & .001 & 88.831 \\
Size & 150 & 5.175 & .608 & 3.068 & 6.53 \\
GR assets & 150 & 2.198 & 22.982 & -1 & 280.618 \\
EGR & 150 & 6.972 & .621 & 6.06 & 7.86 \\
INF & 150 & 5.986 & .56 & 5.51 & 6.99 \\
\hline
\end{tabular}

Among the accounting based performance measures ROA has the lowest average mean (.841) and ROE has the highest mean value (11.046) percent which means that sampled banks earned a return of .841 percent of total assets and 11.046 percent of total equity respectively. The standard deviation, which reflects the variability involved in, is .783 for ROA and 5.037 for ROE respectively. The market performance measurement of $\mathrm{P} / \mathrm{E}$ ratio has the mean value of (15.63), the highest one among the performance measurement used in this study, which indicates that investors are willing to pay a high share price today as they are expecting higher growth opportunities in the banking companies of Bangladesh, with the highest value of 566.02 and lowest value of -20.73 in conjunction with variability, measured by standard deviation, of 60.649 .

For the independent variables used in this study, the average TD ratio is 8.268 , and the LTD ratio is 3.244 with a standard deviation of 32.035 and 15.099 for TD and LTD respectively which suggest that the sampled banks in this study use short term debt more than the long term debt. For other variables applied in this analysis, such as size, EGR and INF have a low level of standard deviation whereas GR (assets) reports a substantial amount of variation from the mean value (22.982).

\subsection{Correlation}

Pairwise correlation analysis was conducted to test the association between capital structure and the performance of banks listed in the Dhaka Stock Exchange. The test results are presented in Table 4. 
Table 4. Matrix of correlations

\begin{tabular}{|c|c|c|c|c|c|c|c|c|c|c|}
\hline Variables & ROA & ROE & EPS & PE Ratio & $\mathrm{TD}$ & LTD & Size & GR assets & EGR & INF \\
\hline ROA & 1.000 & & & & & & & & & \\
\hline ROE & 0.778 & 1.000 & & & & & & & & \\
\hline EPS & 0.389 & 0.561 & 1.000 & & & & & & & \\
\hline PE Ratio & -0.091 & -0.244 & -0.116 & 1.000 & & & & & & \\
\hline TD & 0.008 & -0.049 & -0.033 & -0.022 & 1.000 & & & & & \\
\hline LTD & 0.057 & 0.060 & -0.006 & -0.033 & 0.503 & 1.000 & & & & \\
\hline Size & 0.262 & 0.210 & 0.146 & 0.085 & -0.725 & -0.613 & 1.000 & & & \\
\hline GR assets & -0.010 & 0.031 & 0.004 & -0.017 & 0.207 & 0.459 & -0.261 & 1.000 & & \\
\hline EGR & -0.172 & -0.064 & 0.009 & 0.123 & 0.047 & 0.007 & 0.127 & 0.120 & 1.000 & \\
\hline INF & 0.135 & 0.044 & 0.011 & -0.085 & -0.042 & -0.002 & -0.106 & -0.065 & -0.899 & 1.000 \\
\hline
\end{tabular}

As can be observed from table 4, total debt has a negative association with almost all the bank's performance measurement variables, except for ROA. However, the coefficients are not high between total debt and all other bank performance variables, around more or less than zero. Long term debt has a positive relation between ROA and ROE but negative with EPS and PE ratio. In general, the analysis does not reveal a high correlation between any of the dependent and independent variables. Thus, it can be concluded that the multicollinearity problem does not exist in this analysis, which usually requires correlations between the independent variables of the order of 0.80 or more.

\subsection{Regression results}

To examine the relationship between the capital structure and bank performance multiple regression analysis were conducted in this study. The results of the tests of models 1 to 4 are shown in table 5 below.

Table-5. Regression results

\begin{tabular}{|c|c|c|c|c|}
\hline & Model- 1 & Model- 2 & Model- 3 & Model- 4 \\
\hline IV & ROA & ROE & EPS & PE Ratio \\
\hline LTD & $0.016^{* * *}$ & $0.091^{* * *}$ & 0.011 & -0.054 \\
\hline & $(0.005)$ & $(0.017)$ & $(0.012)$ & $(0.090)$ \\
\hline TD & 0.005 & 0.007 & -0.004 & $0.078^{* *}$ \\
\hline & $(0.004)$ & $(0.025)$ & $(0.005)$ & $(0.037)$ \\
\hline Size & $0.784^{* * *}$ & $3.362^{* * *}$ & 0.430 & 5.298 \\
\hline & $(0.223)$ & $(1.092)$ & $(0.466)$ & $(6.820)$ \\
\hline GR assets & 0.000 & 0.005 & 0.001 & -0.037 \\
\hline & $(0.001)$ & $(0.003)$ & $(0.001)$ & $(0.033)$ \\
\hline EGR & $-0.465 * * *$ & $-1.616^{*}$ & 0.415 & 17.898 \\
\hline & $(0.117)$ & $(0.825)$ & $(0.314)$ & $(15.987)$ \\
\hline INF & $-0.199 *$ & -0.880 & 0.414 & 15.636 \\
\hline & $(0.113)$ & $(0.819)$ & $(0.291)$ & $(15.081)$ \\
\hline
\end{tabular}




\section{MInstitute Macrink $_{\text {Ins }}$}

\begin{tabular}{|l|c|c|c|c|}
\hline Cons. & 1.131 & 9.852 & -4.861 & -232.100 \\
\hline & $(1.574)$ & $(10.972)$ & $(3.778)$ & $(182.623)$ \\
\hline Obs. & 150 & 150 & 150 & 150 \\
\hline R-squared & 0.279 & 0.227 & 0.080 & 0.005 \\
\hline \\
Standard errors are in parenthesis \\
$* * * p<0.01, * * p<0.05, * p<0.1$ \\
\hline
\end{tabular}

The results derived from the regression analysis reveal that the capital structure component of long term debt seems slightly have a positive effect on the performance of the banks measured by ROA and ROE, while there is no impact on the EPS and Price Earning ratio. The result is consistent with (Coleman, 2007; Githire and Muturi, 2015 and Berger and Bonaccora di Patti, 2006) who indicate that the firm's performance is positively associated with capital structure. This result could be explained by the fact that the higher amount of long term debt components presents in the bank's financial statement indicates the acquisition of a large amount of funds by the bank in the form of either debt or fixed deposits. The banks can then convert this fund into the long term loan and give funds to the borrowers at a higher rate of interest which could enhance the profitability of the banks operating in Bangladesh. Besides this, the bank can use the debt to resolve the liquidity crisis and can use this money to pay back the depositors money on the demands of the depositors which enhance the confidence of the bank's customers that ultimately have an impact on the performance of the banks. Also, banks with higher long term debt can enjoy the tax benefits and can go for undertaking long term profitable investments that can influence the performance of the banks. Coleman (2007) explains that long-term debts exert less pressure on the management for repayment and giving management enough time to organize their operations towards the enhancement of profitability. However, this finding is in contrast with (Zeitun and Tian, 2007; Siddik et al., 2017; Amin and Jamil, 2015; Getahun, 2016; Cole et al., 2015; Mehar, 2018) who posit that long term debt has significant negative explanatory power in influencing firm's performance measured by ROA. Again, the result of a positive association of long term debt with ROE is not in line with (Abor 2005; Voung et al., 2017) who reveal a negative association between long term debt ratio and ROE. The result also depicts that total debt has a positive influence on ROA and ROE and negative influence on EPS but the relationship of total debt with all accounting-based performance measurements is not found statistically significant, which is pertinent with Musah and Gakpetor, 2017; Saputra, et al., 2015; Mehar, 2018). This finding is not in line with Ebaid (2009) who reports an increase in total debt is associated with a decrease in ROA. He also suggests that it may happen due to the firm's policy of using a considerable amount of short term debt in its capital structure choices. On the other hand, there is a significant and positive association of total debt with the market-based performance measure of price earning ratio. Furthermore, the results also show that neither total debt nor long term debt has any significant relationship with the bank's performance measured by EPS. This finding is relevant to Vuong et al. (2017) who documents that leverage has no effect on EPS. Again the firm-specific and macroeconomic variables also have no significant influence on the accounting-based performance measurement of EPS. The size of the banks also brings benefits for the banks by showing a positive relationship between the size and ROA and ROE which is supported by the findings of Voung et al. (2017). However, size does not have any impact on the EPS and PE ratio of the banks. Besides that, relating to 
the coefficient of growth variable, the changes in total assets has an insignificant impact on the financial performance of Bangladeshis banks. So, in general, it can be concluded that the bank's growth and profitability are independent. Among the macroeconomic variables, the economic growth rate has a positive association with EPS and PE ratio but none of them is statistically significant. However, the financial performance measured by ROA and ROE is being negatively influenced by the economic growth rate. Finally, this paper finds that inflation is not significantly associated with the performance of measures used in this study except ROA which shows a negative effect of inflation on ROA.

\section{Summary and Conclusion}

Bangladesh is one of the fastest-growing economies in the world. It has been denominated as the new Asian tiger and considered one of the next eleven economies N-11. As a bank dominant financial system, banks can play a pivotal role to achieve the two ambitious goals of 2021 and 2041 fixed by the Bangladesh Government in which Bangladesh wishes to become an upper middle income and a developed country respectively. This study has empirically observed the impact of capital structure choices on the performance of listed banks in Bangladesh as one of the emerging economies. Three accounting-based measurement of firm performance such as ROA, ROE, and EPS and one market-based measurement of firm performance (P/E ratio) have been employed in this study. Empirical findings indicate that long term debt has a positive effect on the performance of banks which is measured in terms of ROA and ROE. This implies that long term debts are associated with the higher performance of banks listed in Bangladesh. One of the reasons might be the banks with long term debt can undertake long term profitable projects which can magnify the profitability. On the other hand, the regression results point to the fact that the capital structure component of total debt has no statistically significant impact on the performance of banks measured by ROA, ROE, and EPS but it has a significant positive impact on the performance of banks measured by price earning ratio. However, this paper further suggests no nexus of Earning per Share (EPS) with any of the capital structure components used in this study. These findings suggest concluding that capital structure has a weak to no influence on the performance of banks in Bangladesh. These findings have significant implications for bank management and policymaker to develop their optimal capital structure policy and it will facilitate to comparison the scenario of the listed banking industry in Bangladesh with the context to the other emerging economies.

The findings of this study would have been more plausible if we could apply a large panel data for this analysis but accessibility and availability of data was a major challenging job. Recognizing the limitations it can be said that this study could serve as a framework for further studies in this field and it opens up the avenue for the banks management to rethink the use of optimal capital structure policy to enhance the profitability of the banks. It would be quite interesting for further research to look into the impact of capital structure on bank's performance incorporating short term debt, total debt to equity as explanatory variables and Tobins' $Q$ as an explained variable. Likewise, further study can be directed to investigate the combined influence of both ownership structure and capital structure on the bank's performance since a large number of shares of Bangladeshi banks are held by family firms. 


\section{References}

Abor, J. (2005). The effect of capital structure on profitability: an empirical analysis of listed firms in Ghana. The Journal of Risk Finance, 6(5), 438-445. https://doi.org/10.1108/15265940510633505

Akintoye, I.R. (2008). Sensitivity of performance to capital structure: a consideration for selected food and beverages companies in Nigeria. Journal of Social Sciences, 7(1), 29-35.

Al-Taani, K. (2013). The Relationship between Capital Structure and Firm Performance: Evidence from Jordan, Journal of Finance and Accounting, 1(3), 41-45. https://doi.org/10.11648/j.jfa.20130103.11

Amin, S. \& Jamil, T. (2015). Capital structure and firm performance: evidence from cement sector of Dhaka Stock Exchange Limited. Journal of Finance and Banking, 13(1\&2), 29-42.

Aramvalarthan, S., Kannadhasan, M., \& Babu, A. (2018). Capital Structure and Corporate Performance: A Study of Indian Pharmaceutical Companies. International Business Management, 12(3), 262-267.

Azeez, O.T., Olanrewaju, E.M., \& Saka, A.T. (2015). Impact of capital structure on corporate performance: a pre and post crisis evaluation of selected companies in US. International Journal of Accounting Research (IJAR), 2(8), 1-20. https://doi.org/10.12816/0017352

Berger, A. \& Bonaccorsi di Patti, E. (2006). Capital structure and firm performance: a new approach to testing agency theory and an application to the banking industry. Journal of Banking and Finance, 30, 1065-1102. https://doi.org/10.1016/j.jbankfin.2005.05.015

Chakraborty, I. (2010). Capital structure in an emerging stock market: The case of India. Research in International Business and Finance, 24(3), 295-314. https://doi.org/10.1016/j.ribaf.2010.02.001

Cole, C., Yan, Y. \& Hemley, D. (2015). Does capital structure impact firm performance: an empirical study of three U.S. sectors. Journal of Accounting and Finance, 15(6), 58-65.

Colemn, A.K. (2007). The impact of capital structure on the performance of microfinance institutions. Journal of Risk Finance, 8(1), 56-71. https://doi.org/10.1108/15265940710721082

Das, C.P., \& Swain, R.K. (2018). Influence of Capital Structure on Financial Performance. Parikalpana: KIIT Journal of Management, 14(1), 161. https://doi.org/10.23862/kiitparikalpana/2018/v14/i1/173256

Demsetz, H., \& Villalonga, B. (2001). Ownership Structure and Corporate Performance. Journal of Corporate Finance, 7, 209-233. https://doi.org/10.1016/S0929-1199(01)00020-7

El-Sayed, E.I. (2009). The impact of capital-structure choice on firm performance: Empirical evidence from Egypt. The Journal of Risk Finance, 10(5), 477-487. https://doi.org/10.1108/15265940911001385 


\section{Ml Macrothink}

Asian Journal of Finance \& Accounting ISSN 1946-052X 2020, Vol. 12, No. 1

Fama, E.F., \& French, K.R. (1998). Taxes, financing decisions, and firm value. The Journal of Finacne, 53(3), 819-843. https://doi.org/10.1111/0022-1082.00036

Frank, M.Z., \& Goyal, V.K. (2003). Testing the pecking order theory of capital structure. Journal of Financial Economics, 67(2), 217-248. https://doi.org/10.1016/S0304405X(02)00252-0

Getahun, M. (2016). Capital structure and financial performance of insurance industries in Ethiopia. Global Journal of Management and Business Research, 16(7), 45-54.

Ghosh, A., \& Jain, P.C. (2000). Financial leverage changes associated with corporate Mergers. Journal of Corporate Finance, 6(4), 377-402. https://doi.org/10.1016/S0929-1199(00)000079

Githire, C. \& Muturi, W. (2015). Effects of capital structure on financial performance of firms in kenya: evidence from firms listed at The Nairobi Securities Exchange. International Journal of Economics, Commerce and Management, United Kingdom, III(4), 1-10.

Goyal, A.M. (2013). Impact of capital structure on performance of listed public sector banks in India. International Journal of Business and Management Invention, 2(10), 35-43.

Hadlock, C. and James, C. (2002). Do banks provide financial slack?. Journal of Finance, 57, 1383-1419. https://doi.org/10.1111/1540-6261.00464

Hossain, M.I., \& Hossain, M.A. (2015). Determinants of capital structure and testing of theories: a study on the listed manufacturing companies in Bangladesh. International Journal of Economics and Finance, 7(4), 176-190. https://doi.org/10.5539/ijef.v7n4p176

Jensen, M.C, \& Meckling, W.H. (1976). Theory of the firm: Managerial behaviour, agency costs and capital structure. Journal of Financial Economics, 3(4), 305-360. https://doi.org/10.1016/0304-405X(76)90026-X

Kahuria, C.W., \& Waweru, G. (2015). Does Capital structure matter? Effects on profitability of firms listed at the Nairobi Securities Exchange. Journal of Business, Economics \& Finance -JBEF (2015), 4(3), 316-330. https://doi.org/10.17261/Pressacademia.2015313055

Khodavandloo, M., Zakaria, Z., \& Nassir, A. M. (2017). Capital structure and firm performance during global financial crisis. International Journal of Economics and Financial Issues, 7(4), 498-506.

Kraus, A., \& Litzenberger, R.H. (1973). A state preference model of optimal financial leverage. Journal of Finance, 28(4), 911-922. https://doi.org/10.1111/j.1540-6261.1973.tb01415.x

Manawaduge, A., Zoysa, A.D., Chowdhury, K., \& Chandarakumara, A. (2011). Capital structure and firm performance in emerging economies: an empirical analysis of Sri Lankan firms. Corporate Ownership \& Control, 8(4), 253-263. https://doi.org/10.22495/cocv8i4c2art2

Mehar, M.R. (2018). Analysis of the Capital Structure and Banks Performance: Evidence from Pakistan. Journal of Business \& Financial Affairs, 7(2), 1-5. https://doi.org/10.4172/21670234.1000343 
Modigliani, F. \& Miller, H. (1958). The cost of capital, corporate finance and the theory of investment. The American Economic Review, 48(3), 261-297.

Mursalim, Mallisa M. \& Kusuma H. (2017). Capital structure determinants and firms' performance: empirical evidence from Thailand, Indonesia and Malaysia. Polish Journal of Management Studies, 1(1), 154-163. https://doi.org/10.17512/pjms.2017.16.1.13

Musah, A. \& Gakpetor, E.D. (2017). Capital structure and firm performance of non-bank financial institutions (NBFIs) in Ghana. Research Journal of Finance and Accounting, 8(14), 32-39.

Mwangi, L.W., Makau, M.S. \& Kosimbei, G. (2014). Relationship between capital structure and performance of non-financial companies listed in the Nairobi Securities Exchange. Kenya Global Journal of Contemporary Research in Accounting, Auditing and Business Ethics (GJCRA), 1(2), 72-90.

Myers, S.C., \& Majluf, N. (1984). Corporate Financing and investment decisions when firms have information that investors do not have. Journal of Financial Economics, 13(2), 187-221. https://doi.org/10.1016/0304-405X(84)90023-0

Nakhaei, M., \& Jafari, S.M. (2015). Survey of the Relationship between Capital Structure and Free Cash Flow with Financial Performance of Companies Listed in Tehran Stock Exchange. Indian Journal of Science and Technology, 8(27), 1-11. https://doi.org/10.17485/ijst/2015/v8i27/82813

Naseem, M.A., Zhang, H., Malik, F., \& Rehman, R.U. (2017). Capital structure and corporate governance. The Journal of Developing Areas, 51(1), 33-47. https://doi.org/10.1353/jda.2017.0002

Nenu, E.A., Vintila, G., \& Gherghina S.C. (2018). The impact of capital structure on risk and firm performance: empirical evidence for the Bucharest Stock Exchange listed companies. International Journal of Financial Studies, 6(41), 1-29. https://doi.org/10.3390/ijfs6020041

Nirajini, A., \& Priya, K.B. (2013). Impact of capital structure on financial performance of the listed trading companies in Sri Lanka. International Journal of Scientific and Research Publications, 3(5), 1-9. https://doi.org/10.5958/j.2249-7137.3.6.001

Oyedokun, G.E., Job-Olatuji, K.A., \& Sanyaolu W.A. (2018). Capital structure and firm financial performance. Accounting \& Taxation Review, 2(1), 56-71.

Pinto, P., Hawaldar, I.Q., Quadras, J.M., \& Joseph, N.R. (2017). Capital structure and financial performance of banks. International Journal of Applied Business and Economic Research, 15(23), 303-312.

Ramaswamy, K. (2001). Organizational ownership, competitive intensity, and firm performance: An empirical study of the Indian manufacturing sector. Strategic Management Journal, 22(10), 989-998. https://doi.org/10.1002/smj.204 


\section{Macrothink}

Asian Journal of Finance \& Accounting ISSN 1946-052X 2020, Vol. 12, No. 1

Rouf, M.A. (2015). Capital Structure and Firm Performance of Listed Non-Financial Companies in Bangladesh. The International Journal of Applied Economics and Finance, 9(1), 25-32. https://doi.org/10.3923/ijaef.2015.25.32

Salim, M., \& Yadav, R. (2012a). Capital Structure and Firm Performance: Evidence from Malaysian Listed Companies. Procedia - Social and Behavioral Sciences, 65, 156-166. https://doi.org/10.1016/j.sbspro.2012.11.105

Saputra, T., Achsani, N.A. \& Anggraeni, L. (2015). The effect of capital structure on firm performance: empirical evidence from the Indonesian financial industry. International Journal of Business and Management Invention, 4(8), 57-66.

Siddik, M.N.A., Kabiraj, S., \& Joghee, S. (2017) Impacts of Capital Structure on Performance of Banks in a Developing Economy: Evidence from Bangladesh. International journal of Finance studies 5,13Int. J. Financial vol. 5(13), 1-13. https://doi.org/10.3390/ijfs5020013

Simerly, R.L., \& Li, M. (2000). Environmental dynamism, capital structure and performance: A theoretical integration and an empirical test. Strategic Management Journal, 21(1), 31-49. https://doi.org/10.1002/(SICI)1097-0266(200001)21:1<31::AID-SMJ76>3.0.CO;2-T

Vuong, N.B, Vu, T.T.Q. \& Mitra, P. (2017). Impact of capital structure on firm's financial performance: evidence from United Kingdom. Journal of Finance \& Economics Research, 2(1), 18-31. https://doi.org/10.20547/jfer1702102

Zeitun, R. \& Tian, G. G. (2007). Capital structure and corporate performance: evidence from Jordan. Australasian Accounting Business and Finance Journal, 1(4), 40-61. https://doi.org/10.14453/aabfj.v1i4.3 